\title{
GROWTH FACTORS AND CHROMOGRANIN A IN INTRA-ABDOMINAL ADHESIONS OF CHILDREN
}

\author{
Māra Pilmane ${ }^{1}$, Kaiva Zīle Zarin̦A ${ }^{1}$, Zane Ābola ${ }^{2}$ \\ ${ }^{1}$ Institute of Anatomy and Anthropology \\ ${ }^{2}$ Department of Paediatric Surgery, Riga Stradiňš University, Riga, Latvia
}

\begin{abstract}
Pathogenesis of adhesions is still unclear and does not give a clear response whether the morphopathogenetic mechanisms of congenital and acquired adhesions in children are different or not. Thus, we searched for the appearance and distribution of growth factors, their receptors and chromogranins in adhesions of children in the ontogenetic aspect.

Tissues were obtained from 17 children of group 1 ( 1 day to 3 years old) and 10 children of group 2 (10 to 16 years old). Visibly intact peritoneum was obtained from teenagers of group 2 and used as control tissue. Routine staining and immunohistochemistry for insulin-like growth factor 1 (IGF1), insulin-like growth factor 1 receptor (IGF IR), transforming growth factor beta (TGF- $\beta$ ), hepatocyte growth factor (HGF), chromogranin A (CgA) was applied.

Statistical analysis included semi-quantitative evaluation of immunopositive structures, Wilcoxon signed-rank test and Wilcoxon rank sum test for comparison of data.

The results showed patchy fibrosis with round-shaped fibroblasts, neoangiogenesis and inflammation. Adhesions in group 1 demonstrated various appearance of IGF, IGF IR, few to moderate number of TGF- $\beta$-, HGF- and moderate number of CgA-containing cells. In both groups, fibroblasts predominated among actively expressing cells. Group 2 showed moderate to numerous IGFI and HGF positive cells, while IGF IR- and TGF- $\beta$-containing cells were numerous. Intact peritoneum showed variable TGF- $\beta, \mathrm{CgA}$, and few to moderate HGF, IGFI, IGF IR cells.

In conclusion, an increase in IGFI, IGF IR, TGF- $\beta$ and HGF characterises the acquired ("aged") adhesions. Fibroblasts are most active in adhesion
\end{abstract}


formation with the increase of cellular activity during the aging of children and adhesions. Fibroblasts with changes in shape stimulate further development of disease via intensive CgA expression.

Keywords: growth factors; receptors; chromogranins; adhesions; children; ontogenesis

\section{INTRODUCTION}

Adhesions are bands of scar tissue that bind two parts of tissue together. Although adhesions can occur anywhere, the most common locations are within the stomach, the pelvis, and the heart. Peritoneal adhesions are nearly inevitable after laparotomy and a major cause of misery for both patients and physicians [1].

Intra-abdominal adhesions may be congenital or acquired. Congenital adhesions arise during physiological organogenesis - like a frequently observed attachment of the sigmoid colon to the left pelvic wall - or can be traced back to abnormal embryonic development of the abdominal cavity. They are usually asymptomatic and are diagnosed incidentally [2]. Postinflammatory adhesions are caused by intra-abdominal inflammation or can be attributed to endometriosis, peritonitis, radiotherapy, or long-term peritoneal dialysis [2-4].

Since intra-abdominal adhesions arise from aberrant peritoneal wound healing processes, any mesothelial damage by surgical trauma or bacterial inflammation can lead to their formation [5]. Damage to the peritoneum is followed by capillary bleeding and increased vascular permeability with consequent exudation of fibrinogen $[4,5]$. When tissue damage is associated with vascular insufficiency, adhesions form to prevent ischemic injury [6]. Additionally, connective tissue cells and different growth factors have been mentioned to participate in the pathogenesis of adhesion formation. So, as a result of surgical injury, activated macrophages and peritoneal mesothelial cells secrete pro-inflammatory cytokine and growth factor TGF- $\beta[7,8]$; increased levels of cytokines have also been shown to play a role in intestinal diseases $[9,10]$ and in the formation of adhesion bands and can impair peritoneal fibrinolysis [11]. Generally, TGF- $\beta$ influences tissue embryogenesis, physiological functioning of cells, inflammatory processes and tissue regeneration [12,13]. Besides this, the insulin-like growth factors constitute a family of peptides which perform broad anabolic and mitogenic action in a wide variety of tissues [14]. On the other hand, insulin-like growth factor I receptors (IFGIR), mainly produced 
by adhesion fibroblasts, are also thought to be involved in fibrosis development [15]. Finally, the hepatocyte growth factor (HGF) mediates the motility of smooth muscle cells in the adhesion blood vessels [16], while the endotheliocyte shape is modulated here by chromogranins [17]. Although all the abovementioned factors are seemingly involved in the common adhesion development, there is no data regarding the appearance of these factors in the ontogenetic aspects. Thus, the aim of this study was to research the distribution and relative frequency of growth factors and chromogranins in the intra-abdominal adhesions in children of different ages with different invasive treatment history.

\section{MATERIALS AND METHODS}

\section{Patient information}

Adhesion tissues were collected from 17 patients aged from 1 day to 3 years (9 female and 8 male patients) (group 1, Table 1) and from 10 patients aged from 10 to 17 years (4 female and 6 male patients) (group 2, Table 2) undergoing laparotomy at the Surgery Department of the Children's University Clinical Hospital, Latvia. The study was approved by the Riga Stradinšs University Ethics Committee (10.05.2007), and parents of patients have given written informed consent for participation in the trial. All group 1 patients underwent first-time abdominal operations due to adhesions. From group 2, only the first patient underwent surgery for the first time, while all the others had already been operated at an earlier age, and the time differences between the surgeries varied from 1-5 years. All specimens of intra-abdominal adhesions were marked with data from the site of the operation. From group 2, macroscopically unchanged peritoneum of four patients was also obtained and used as control material for this age group. Samples of 5-10 mm were excised from serous surfaces between opposing visceral organs and the parietal peritoneum. Tissue specimens were immediately fixed in $10 \%$ formalin solution. 
Table 1. Information about the patients of group 1

\begin{tabular}{|c|c|c|c|c|}
\hline No & Sex & Age & Diagnosis & Adhesion site \\
\hline 1. & M & 1 day & $\begin{array}{l}\text { Multiple anomalies (oesophageal } \\
\text { atresia, distal tracheoesophageal } \\
\text { fistule, duodenal atresia) }\end{array}$ & duodenum \\
\hline 2. & $\mathrm{~F}$ & 1 day & Jejunal atresia & jejunum \\
\hline 3. & $\mathrm{~F}$ & 2 days & $\begin{array}{l}\text { Duodenal stenosis. Ladd } \\
\text { ligament. Malrotation }\end{array}$ & intra-abdominal adhesions \\
\hline 4. & $\mathrm{~F}$ & 5 days & Duodenal atresia. Ladd ligament & duodenum \\
\hline 5. & $\mathrm{~F}$ & 1 week & Duodenal atresia & intra-abdominal adhesions \\
\hline 6. & M & 2 weeks & Pancreas anulare & intra-abdominal adhesions \\
\hline 7. & $\mathrm{~F}$ & 3 weeks & Ileostomal stenosis & intra-abdominal adhesions \\
\hline 8. & M & 1.5 months & Ileus acuta & intra-abdominal adhesions \\
\hline 9. & M & 1.5 months & Ladd ligament & Ladd ligament \\
\hline 10. & M & 2.5 months & $\begin{array}{l}\text { Status after necrotic enterocol- } \\
\text { itis. Stenosis of colon ascendens }\end{array}$ & $\begin{array}{l}\text { intra-abdominal adhesions } \\
\text { and Ladd ligament }\end{array}$ \\
\hline 11. & M & 3 months & $\begin{array}{l}\text { Necrotic enterocolitis with multi- } \\
\text { ple perforations. Ileostoma }\end{array}$ & ileum \\
\hline 12. & M & 4 months & $\begin{array}{l}\text { Status after necrotic enterocolitis. } \\
\text { Colostoma }\end{array}$ & colon \\
\hline 13. & $\mathrm{~F}$ & 4.5 months & Ileus acuta & intra-abdominal adhesions \\
\hline 14. & $\mathrm{~F}$ & 7 months & $\begin{array}{l}\text { Necrotic enterocolitis, peritonitis, } \\
\text { colon descendens perforation, } \\
\text { ileostoma }\end{array}$ & intra-abdominal adhesions \\
\hline 15. & M & 8 months & Ileus acuta & intra-abdominal adhesions \\
\hline 16. & $\mathrm{~F}$ & 2.2 years & Ileus acuta & ileum \\
\hline 17. & $\mathrm{~F}$ & 3.4 years & $\begin{array}{l}\text { Diaphragmal herniation. } \\
\text { Rotation disorders }\end{array}$ & intra-abdominal adhesions \\
\hline
\end{tabular}

M - male; F - female. 
Table 2. Information about the patients of group 2

\begin{tabular}{|c|c|c|c|c|}
\hline No & Sex & $\begin{array}{l}\text { Age } \\
\text { (years) }\end{array}$ & Diagnosis & Adhesion site \\
\hline 1. & M & 10 & $\begin{array}{l}\text { Status after appendectomy. } \\
\text { Intra-abdominal adhesions }\end{array}$ & peritoneum \\
\hline \multirow[t]{2}{*}{2.} & \multirow[t]{2}{*}{ M } & \multirow[t]{2}{*}{10} & \multirow{2}{*}{$\begin{array}{l}\text { Ileus recidiva. Intra- } \\
\text { abdominal adhesions }\end{array}$} & 1. peritoneum \\
\hline & & & & 2. appendix vermiformis \\
\hline \multirow[t]{3}{*}{3.} & \multirow[t]{3}{*}{ M } & \multirow[t]{3}{*}{10} & \multirow{3}{*}{$\begin{array}{l}\text { Ileus acuta. Intra-abdominal } \\
\text { adhesions }\end{array}$} & 1. colon \\
\hline & & & & 2. omentum majus \\
\hline & & & & 3. peritoneum intactum (control tissue) \\
\hline \multirow[t]{3}{*}{4.} & \multirow[t]{3}{*}{$\mathrm{F}$} & \multirow[t]{3}{*}{12} & \multirow{3}{*}{$\begin{array}{l}\text { Status after appendectomy. } \\
\text { Intra-abdominal adhesions }\end{array}$} & 1. appendix vermiformis \\
\hline & & & & 2. colon ascendens \\
\hline & & & & 3. peritoneum intactum (control tissue) \\
\hline \multirow[t]{4}{*}{5.} & \multirow[t]{4}{*}{ M } & \multirow[t]{4}{*}{13} & \multirow{4}{*}{$\begin{array}{l}\text { Ileus recidiva. Status } \\
\text { after appendectomy. } \\
\text { Intra-abdominal adhesions }\end{array}$} & 1. colon \\
\hline & & & & 2. peritoneum \\
\hline & & & & 3. peritoneum intactum (control tissue) \\
\hline & & & & 4. ileum \\
\hline \multirow[t]{4}{*}{6.} & \multirow[t]{4}{*}{$\mathrm{F}$} & \multirow[t]{4}{*}{15} & \multirow{4}{*}{$\begin{array}{l}\text { Status after appendectomy. } \\
\text { Intra-abdominal adhesions }\end{array}$} & 1. peritoneum-caecum \\
\hline & & & & 2. peritoneum-colon ascendens \\
\hline & & & & 3. peritoneum intactum (control tissue) \\
\hline & & & & 4. peritoneum-appendix vermiformis \\
\hline \multirow[t]{2}{*}{7.} & \multirow[t]{2}{*}{ M } & \multirow[t]{2}{*}{15} & \multirow{2}{*}{$\begin{array}{l}\text { lleus due to intra- } \\
\text { abdominal adhesions }\end{array}$} & 1. peritoneum \\
\hline & & & & 2. peritoneum \\
\hline \multirow[t]{4}{*}{8.} & \multirow[t]{4}{*}{$\mathrm{F}$} & \multirow[t]{4}{*}{15} & \multirow{4}{*}{$\begin{array}{l}\text { lleus due to intra- } \\
\text { abdominal adhesions }\end{array}$} & 1. peritoneum-colon ascendens \\
\hline & & & & 2. peritoneum-appendix vermiformis \\
\hline & & & & 3. peritoneum -ileum \\
\hline & & & & 4. peritoneum -colon sigmoideus \\
\hline 9. & M & 16 & $\begin{array}{l}\text { Ileus recidiva. Intra- } \\
\text { abdominal adhesions }\end{array}$ & peritoneum-ileum-omentum majus \\
\hline 10. & $\mathrm{~F}$ & 16 & $\begin{array}{l}\text { Intra-abdominal } \\
\text { adhesions (surgery of } \\
\text { presacral teratoma in age } \\
\text { of } 4 \text { months) }\end{array}$ & colon ascendens \\
\hline
\end{tabular}

$\mathrm{M}$ - male; $\mathrm{F}$ - female; red marks the intact peritoneum. 


\section{Immunohistochemistry}

Multiple $6 \mu \mathrm{m}$ thick sections of paraffin-embedded abdominal adhesion tissues were routinely stained with haematoxylin and eosin (H\&E). Standard immunohistochemistry (IMH) was done according to Hsu et al [18]. Prior to immunostaining, sections were deparaffinised and rehydrated. Sections were processed in microwave for $20 \mathrm{~min}$ in $4 \%$ citrate buffer ( $\mathrm{pH} \mathrm{10}$ ), quenched for 10 min with $3 \% \mathrm{H}_{2} \mathrm{O}_{2}$ to block endogenous peroxidase activity, rinsed in phosphate-buffered saline ( $\mathrm{pH}$ 7.4), pre-treated with a non-immune goat serum for $10 \mathrm{~min}$ to block nonspecific antibody binding and then incubated for $2 \mathrm{~h}$ with the primary antibodies. The primary antibodies utilized in immunohistochemistry were rabbit polyclonal antibodies specific for hepatocyte growth factor (HGF, dilution 1:300, R\&D System, DE), insulin-like growth factor 1 (IGF1, dilution 1:50, R\&D System, DE), insulin-like growth factor 1 receptor (IGF IR, dilution 1:100, R\&D System, DE), transforming growth factor beta (TGF- $\beta$, dilution 1:1000, Abcam, UK), chromogranin A (CgA, dilution 1:100, DakoCytomation, DK). Immunoreaction was visualized by the avidin-biotin (LSAB) immunoperoxidase method using an LSAB kit (DakoCytomation, DK). DAB (3, 3-diamino-benzidine) solution (DakoCytomation, DK) was used to develop the signals (brown colour) and haematoxylin was used for counterstaining.

\section{Statistical analysis}

Semi-quantitative analysis was used to estimate the proportions of immunopositive structures in abdominal adhesions [19]. The designations were as follows: 1 - few positive structures in the view field; 2 - moderate and 3 - numerous positive structures in the view field. Statistical analysis was carried out using the STATA 9.2 intercooled (State Corp, Texas, USA). For statistical analysis of the distribution of immunopositive structures the Wilcoxon signed-rank test (for comparison between intact and average data) and Wilcoxon rank sum test (for comparison between data of children [group 1] and adolescents [group 2]) was used. P-value $<0.05$ on 2 -tailed test was considered statistically significant.

\section{RESULTS}

Routine staining demonstrated patchy fibrosis with round-shaped fibroblasts. Neoangiogenesis was also remarkable in fibrosis regions. Perivascular invasion with inflammatory cells was noted in three cases of group 1 patients and in half of group 2 patients (Fig 1). Regional accumulation with macrophages was also 
detected among fibrotic tissue. Mesothelial cells demonstrated changed shape only in two cases.

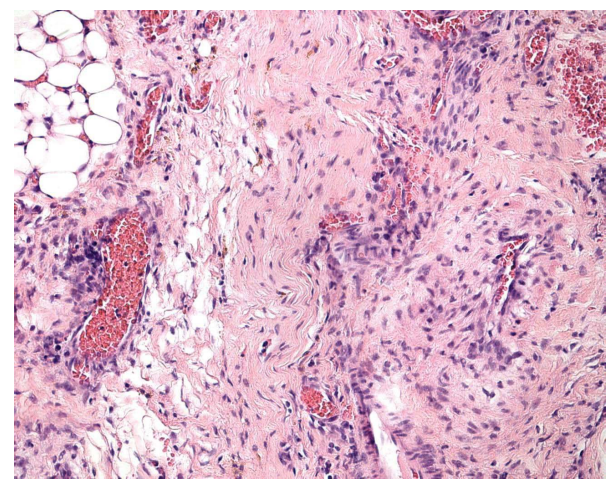

Figure 1. Typical micrograph of adhesions with fibrosis, neoangiogenesis and perivascular infiltration of tissue with inflammatory cells. Boy of 10 years of age, group 2. Haematoxylin and eosin, $\times 250$.

As adhesions of all sites were similar in expression of growth factors and chromogranin A, we did not focus on analysis of different growth factors regarding the adhesion site.

Altogether, in group 1, few adhesion cells expressed IGFI, few to moderate cells - IGF IR and TGF- $\beta$, moderate number of cells - CgA, but moderate to numerous - HGF (Table 3). The number of IGFI-, IGF IR and TGF- $\beta$ containing structures increased in the group 2 adhesions, while there was no difference between HGF and CgA positive cells in adhesions of younger (group 1) and older children (group 2) (Figs 2-7). Significant difference $(\mathrm{P}<0.05)$ was observed between the number of positive structures for IGFI, IGF IR and TGF- $\beta$ in adhesions of groups 1 and 2.

Table 3. Relative average number of growth factors and chromogranin A-containing cells in adhesion tissues in children of different age groups

\begin{tabular}{lccccc}
\hline \multicolumn{1}{c}{ Factors } & IGFI & IGF IR & TGF- & HGF & CgA \\
\hline $\begin{array}{l}\text { Group } 1 \text { (newborns and early } \\
\text { childhood) } \mathrm{n}=17\end{array}$ & $+*$ & $+/++^{*}$ & $+/++^{*}$ & $++/+++$ & ++ \\
\hline $\begin{array}{l}\text { Group 2 (late childhood and } \\
\text { adolescents) } \mathrm{n}=10\end{array}$ & ++ & $++/+++$ & +++ & $++/+++$ & ++ \\
\hline
\end{tabular}

* - statistically significant difference $(P<0.05)$

HGF - hepatocyte growth factor, IGF1 - insulin-like growth factor 1, IGF IR - insulin-like growth factor 1 receptor, TGF- $\beta$ - transforming growth factor beta, CgA - chromogranin A. 


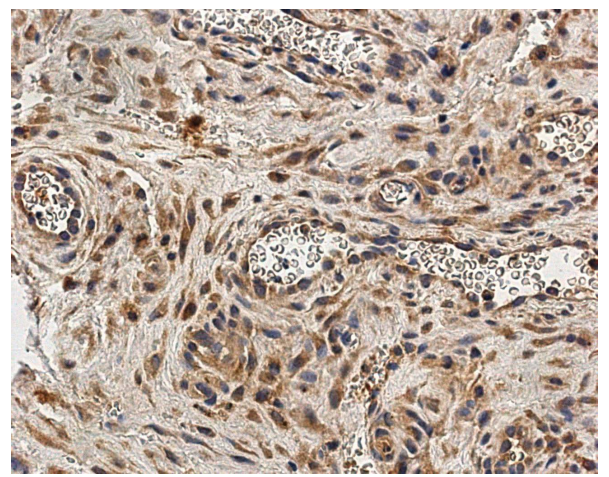

Figure 2. Micrograph of chromogranin A-containing structures in adhesions of an 8-monthold child. Chromogranin A IMH, X 400.

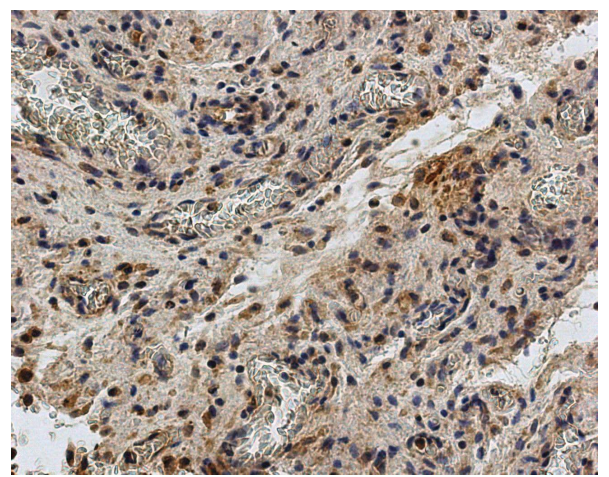

Figure 4. Micrograph of IGFI immunoreactive fibroblasts and macrophages in the acquired adhesion group. Girl, age 15 years. IGFI IMH, X 400 .

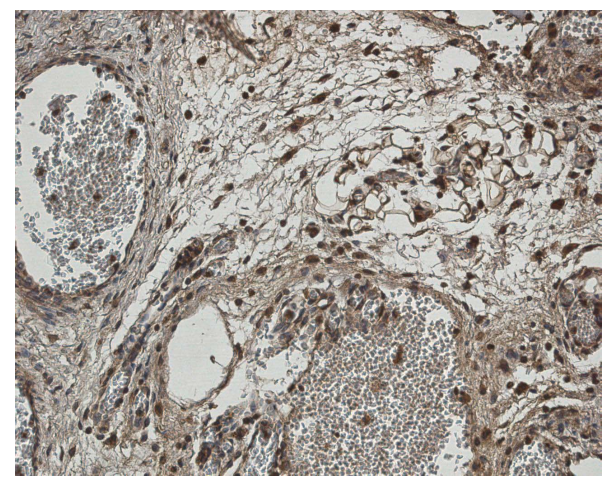

Figure 6. Micrograph of numerous IGF IR immunoreactive connective tissue cells in acquired group adhesions. Girl, age 15 years. IGF IR IMH, $\times 250$.

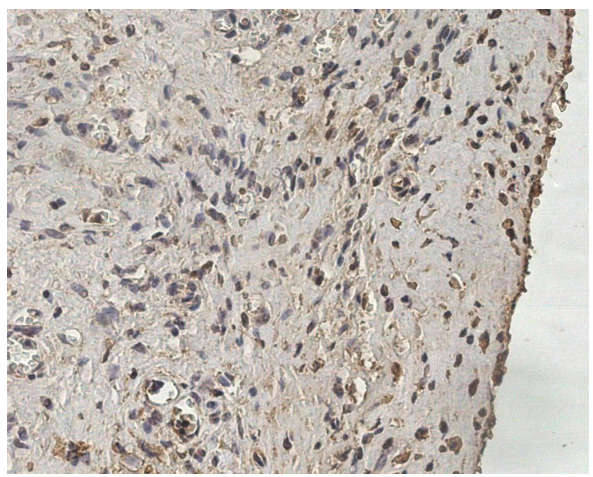

Figure 3. Micrograph of IGFI positive structures in the congenital adhesion group. Patient age 4.5 months. IGFI IMH, X 400.

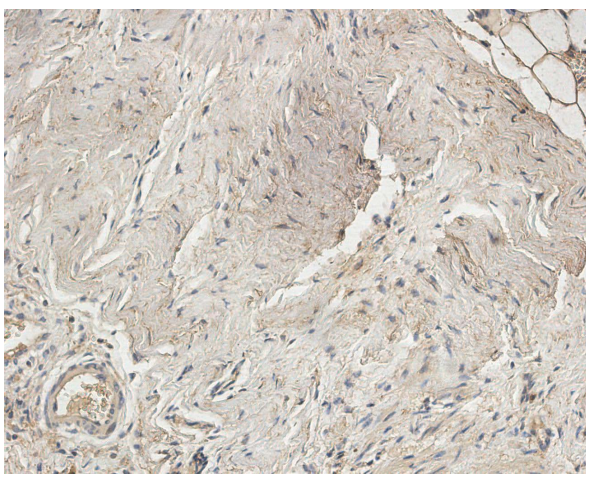

Figure 5. Micrograph of few IGF IR immunoreactive fibroblasts in congenital group adhesions. Girl, age 2.2 years. IGF IR IMH, X 250.

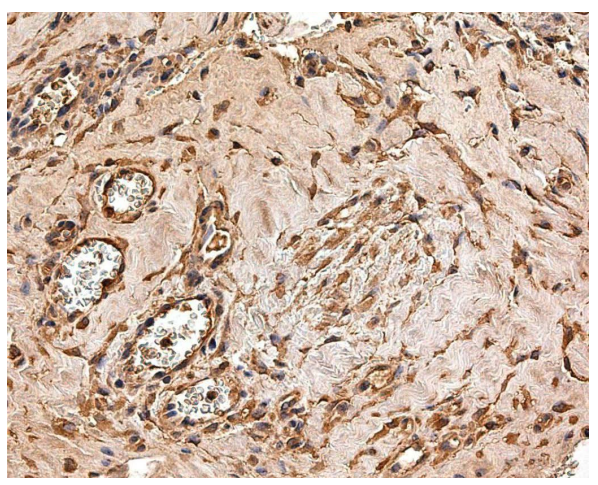

Figure 7. Micrograph of numerous HGF expressing fibroblasts in acquired adhesions of a 10-year-old boy. HGF IMH, X 250. 
Moderately strong correlation was observed between TGF- $\beta$ and HGF $(\mathrm{R}=0.48)$ expressing structures, as well as between HGF and CgA $(\mathrm{R}=0.47)$ structures in adhesions of our youngest patients.

From the comparison of immunoreactive structures between adhesion site and intact peritoneum, statistically significant difference $(\mathrm{P}<0.05)$ was observed between the relative number of IGF IR, TGF- $\beta$ and HGF immunoreactive structures (Table 4 ).

Table 4. Relative average number of growth factors and chromogranin A-containing structures in adhesions of late childhood and adolescent group (group 2) and intact peritoneum

\begin{tabular}{lccccc}
\multicolumn{1}{c}{ Factors } & IGFI & IGF IR & TGF- 3 & HGF & CgA \\
\hline Adhesions $\mathrm{n}=10$ & ++ & $++/+++^{*}$ & $+++^{*}$ & $++/+++^{*}$ & ++ \\
\hline Intact peritoneum $\mathrm{n}=4$ & ++ & + & ++ & $+/++$ & ++ \\
\hline
\end{tabular}

* - statistically significant difference $(P<0.05)$

HGF - hepatocyte growth factor, IGF1 - insulin-like growth factor 1, IGF IR - insulin-like growth factor 1 receptor, TGF- $\beta$ - transforming growth factor beta, CgA - chromogranin A.

Moderately strong correlation was observed between IGFI- and IGF IR-containing structures $(\mathrm{R}=0.64)$, as well as between the number of HGF and $\mathrm{CgA}(\mathrm{R}=0.66)$ immunoreactive structures in adhesions of older children.

From cells, mainly fibroblasts (and to a lesser extent also endotheliocytes) were the ones showing the richest expression properties for growth factors and chromogranin A, while only occasional and/or few mesothelial cells and inflammatory cells demonstrated different factor expression in some cases in group 1. Due to this fact and the presence in the intact peritoneum, the fibroblast expression for different factors was compared in group 2. A significant difference $(\mathrm{P}<0.05)$ was seen between positive fibroblasts expressing IGF IR, $\mathrm{HGF}$ and $\mathrm{CAB}$ in adhesions and intact peritoneum (Table 5).

Table 5. Relative average number of growth factors and chromogranin A-containing fibroblasts in adhesions of late childhood and adolescent group (group 2) and intact peritoneum

\begin{tabular}{lccccc}
\hline \multicolumn{1}{c}{ Factors } & IGFI & IGF IR & TGF- $\beta$ & HGF & CgA \\
\hline Adhesions $\mathrm{n}=10$ & $++/+++$ & $++/+++*$ & +++ & $++/+++{ }^{*}$ & $++/+++{ }^{*}$ \\
\hline Intact peritoneum $\mathrm{n}=4$ & ++ & $+/++$ & ++ & $+/++$ & ++ \\
\hline
\end{tabular}

* statistically significant difference $(P<0.05)$

HGF - hepatocyte growth factor, IGF1 - insulin-like growth factor 1, IGF IR - insulin-like growth factor 1 receptor, TGF- $\beta$ - transforming growth factor beta, CgA - chromogranin A. 
A strong correlation $(\mathrm{R}=0.8)$ was observed between the number of IGFI- and IGF IR-containing fibroblasts, but a moderately strong correlation $(\mathrm{R}=0.6)$ was detected between the numbers of HGF and $\mathrm{CgA}$ positive fibroblasts of the children with a longer history of adhesions.

\section{DISCUSSION}

We detected a statistically significant difference in the expression of TGF- $\beta$, IGFI, IGF IR between the congenital adhesion tissue and those of older children, including adolescents. TGF- $\beta$ might be an important trigger of extracellular matrix production and deposition [20]. Thus, we speculate on intensification of its function with the "aging of adhesions" and the following more prominent appearance of fibrosis. The last one is probably also stimulated by IGFI which is known to increase collagen mRNAs synthesis in intestinal smooth muscle cells [21]. An interesting observation is the medium strong correlation of HGF and TGF- $\beta$ in the congenital adhesion group. Probably this is explained by the role of HGF which is a factor that blocks fibroblast function to produce the extracellular matrix in cultures [22] and also acts as a compensatory mechanism in the early formation of adhesion tissues. However, this mechanism seems to have changed later because the abovementioned correlation disappeared in our patients with "older" adhesions. Thus, our results disagree with Liu et al [23] who reported that local application of recombinant adenovirus carrying the HGF gene reduced adhesion formation in rats.

Insulin-like growth factors I and II (IGFI and IGFII) are also potent mitogens that stimulate wound healing by increasing collagen synthesis in fibroblasts [24]. Besides mediating the growth and proliferation of smooth muscle cells [20], many papers also describe the impact of TGF- $\beta$ and IGFI on the endothelium [25]. The presence of neoangiogenesis characteristic of adhesions in our patients additionally proves a role of IGFI which is essential for normal vascularisation and also stimulates angiogenesis [26]. However, the increase of IGFI is not that simple and might appear to be in contrast to the endothelial dysfunction through anti-apoptotic and anti-inflammatory properties provided by this factor [27].

HGF expression was similar in adhesions between groups 1 and 2 but differed between the adhesions of group 2 and the intact peritoneum. The correlation between the HGF and $\mathrm{CgA}$ in all adhesion patients was significant. Chromogranin A, a glycoprotein stored and co-released with various hormones by neuroendocrine cells and neurons, and widely seen in non-neuronal cells 
fibroblasts in adhesions of our patients, can modulate cell adhesion [28]. Moreover, this function is provided by chromogranin A N-terminal fragment vasostatin-1 which is responsible for the cytoskeleton changes [29] and explains the changed shape of these connective tissue cells observed not only by us but also by the above-mentioned authors.

As HGF inhibits TGF- $\beta$ and collagen III in fibroblasts [30], the HGF-CgA interaction seems to be an important adhesion formation regulatory mechanism in morphopathogenesis of adhesion disease. Until now, the complex functional role for HGF and TGF- $\beta$ has been described in studies about mammary tumours that show a tumour-suppressive role of TGF- $\beta$ signalling fibroblasts, in part by suppressing HGF signalling between fibroblasts and epithelial cells [31]. In a study of cancerogenesis, the increase in fibroblast released HGF is suggested to stimulate the development of invasive tumours [32]. Probably, this reversal function when HGF blocks the secretion of extracellular matrix from fibroblasts but stimulates the migration of connective tissue cells is essential for fibrosis and further adhesion formation.

Additionally, HGF is known to prevent endothelial cell death [33] and has an opposite effect on fibrogenic stimulation of TGF- $\beta 1$ [34]. HGF regulates key inflammatory events that are common to many diseases and organ systems, including suppression of apoptosis [35] and enhancing of matrix degradation $[34,36]$.

A strong correlation between the number of IGFI- and IGF IR-containing fibroblasts was detected in children with a longer history of adhesion illness, and generally both factors here were notably marked in comparison to the congenital adhesions. Similar data have also been found by other authors who report the increased expression of these factors from the culture of adhesion fibroblasts [15]. Thus, we can speculate about intensified cellular proliferation, survival, differentiation, and transformation, which has been mentioned to be a common result in the functions of IGFI and IGF IR [37]. Generally, these molecular events influence the connective tissue cells like fibroblasts and are especially intensive in long-time adhesions.

Our study proved the influence of mesodermal derived growth factors like IGFI and its receptor, TGF- $\beta$, and HGF in the development of adhesions and indicated the main role of $\mathrm{CgA}$ expressing fibroblasts into the development of adhesion fibrosis in children of different ages, which do not depend on the adhesion site in the abdominal cavity. 


\section{CONCLUSIONS}

Acquired adhesions (in adolescents and postsurgical patients) demonstrate a strong increase of IGFI, IGF IR, and TGF- $\beta$ expression that proves their role in adhesion modulation and in pathogenesis of adhesion disease.

HGF selectively elevates only in adhesions of older children and thus might depend not only on the disease process but also on aging.

From all the cells involved in adhesion formation, the most active are fibroblasts followed by endothelial cells and mesothelium. The cellular activity seems to increase with the age of patients and probably also depends on other factors (duration of disease, complications, etc.). Development of adhesions changes the shape of fibroblasts, which stimulates the further development of disease via intensive $\mathrm{CgA}$ expression.

\section{REFERENCES}

1. Cahill R.A., Redmond H.P. (2008). Cytokine orchestration in post-operative peritoneal adhesion formation. World J Gastroenterol, 14, 4861-4866. https://doi.org/10.3748/wjg.14.4861

2. Liakakos T., Thomakos N., Fine P.M., Dervenis C., Young R.L. (2001). Peritoneal adhesions: aetiology, pathophysiology, and clinical significance. Dig Surg, 18(4), 260-273. https://doi.org/10.1159/000050149

3. Monk B.J., Berman, M.L., Montz, F.J. (1994). Adhesions after extensive gynecologic surgery: clinical significance, etiology, and prevention. Am J Obstet Gynecol, 170 (5Pt1), 1396-1403. https://doi.org/10.1016/S0002-9378(94)70170-9

4. Cheong Y.C., Laird S.M., Li T.C., Shelton J.B., Ledger W.L., Cooke I.D. (2001). Peritoneal healing and adhesion formation/reformation. Human Reprod Update, 7, 556-566. https://doi.org/10.1093/humupd/7.6.556

5. Reed K.L., Fruin A.B., Bishop-Bartolomei K.K., Gower A.C., Nicolaou M., Stucchi A.F., Leeman S.E., Becker J.M. (2002). Neurokinin-1 receptor and substance P messenger RNA levels increase during intraabdominal adhesion formation. J Surg Res, 108, 165-172. https://doi.org/10.1006/jsre.2002.6533

6. Ellis H. (1982). The causes and prevention of intestinal adhesions. Br J Surg, 69, 241-243. https://doi.org/10.1002/bjs.1800690502

7. Chegini N. (1997). The role of growth factors in peritoneal healing: transforming growth factor beta (TGF-beta). Eur J Surg Suppl, 577, 17-23. PMID: 9076448

8. Saed G.M., Kruger M., Diamond M.P. (2004). Expression of transforming growth factor-beta and extracellular matrix by human peritoneal mesothe- 
lial cells and by fibroblasts from normal peritoneum and adhesions: effect of Tisseel. Wound Repair Regen, 12, 557-564.

https://doi.org/10.1111/j.1067-1927.2004.012508.x

9. Rezaie A., Ghorbani F., Eshghtork A., Zamani M.J., Dehghan G., Taghavi B., Nikfar S., Mohammadirad A., Daryani N.E., Abdollahi M. (2006). Alterations in salivary antioxidants, nitric oxide, and transforming growth factor- $\beta 1$ in relation to disease activity in Crohn's disease patients. Ann N Y Acad Sci, 1091, 110-122. https://doi.org/10.1196/annals.1378.060

10. Rezaie A., Khalaj S., Shabihkhani M., Nikfar S., Zamani M.J., Mohammadirad A., Daryani N.E., Abdollahi M. (2007). Study on the correlations among disease activity index and salivary transforming growth factor- $\beta 1$ and nitric oxide in ulcerative colitis patients. Ann N Y Acad Sci, 1095, 305-314. https://doi.org/10.1196/annals.1397.034

11. Holmdahl L., Kotseos K., Bergstrom M., Falk P., Ivarsson M.L., Chegini N. (2001). Overproduction of transforming growth factor-betal (TGF-beta1) is associated with adhesion formation and peritoneal fibrinolytic impairment. Surgery, 129, 626-632. https://doi.org/10.1067/msy.2001.113039

12. Zhu H.J., Burgess A.W. (2001). Regulation of transforming growth factor-beta signaling. Mol Cell Biol Res Commun, 4, 321-330.

https://doi.org/10.1006/mcbr.2001.0301

13. Philipp K., Riedel F., Sauerbier M., Hörmann K., Germann G. (2004). Targeting TGF-beta in human keratinocytes and its potential role in wound healing. Int J Mol Med, 14, 589-593. PMID: 15375586.

https://doi.org/10.3892/ijmm.14.4.589

14. Caiola S., Di Biase N., Buongiorno A.M. (1992). Somatomedins/insulin-like growth factors (IGFs): chemical and functional characteristics. Ann Ist Super Sanita, 28, 553-561. www.Pag553_561Vol28N41992.pdf

15. Rizk N.N., Saed G.M., Diamond M.P. (2006). Effects of hyperglycemia on the differential expression of insulin and insulin-like growth factor-I receptors in human normal peritoneal and adhesion fibroblasts. Fertil Steril, 86(4Suppl), 1217-1222. https://doi.org/10.1016/j.fertnstert.2006.04.022

16. Ma H., Calderon T.M., Kessel T., Ashton A.W., Berman J.W. (2003). Mechanisms of hepatocyte growth factor-mediated vascular smooth muscle cell migration. Circ Res, 93, 1066-1073. https://doi.org/10.1161/01.RES.0000102867.54523.7F

17. Colombo B., Longhi R., Marinzi C., Magni F., Cattaneo A., Yoo S.H., Curnis F., Corti A. (2002). Cleavage of chromogranin A N-terminal domain by plasmin provides a new mechanism for regulating cell adhesion. J Biol Chem, 277, 45911-45919. https://doi.org/10.1074/jbc.M202637200

18. Hsu S., Raine L., Fanger H. (1981). The use of antiavidin antibody and avidinbiotin peroxidase complex in immunoperoxidase technics. Am J Clin Pathol, 75, 816. https://doi.org/10.1093/ajcp/75.6.816 
19. Pilmane M., Luts A., Sundler F. (1995). Changes in neuroendocrine elements in bronchial mucosa in chronic lung disease in adults. Thorax, 50, 551-554. https://doi.org/10.1136/thx.50.5.551

20. Stracke S., Konner K., Kostlin I., Friedl R., Jehle P.M., Hombach V., Keller F., Waltenberger J. (2002). Increased expression of TGF- $\beta 1$ and IGF-I in inflammatory stenotic lesions of hemodialysis fistulas. Kidney International, 61, 1011-1019. https://doi.org/10.1046/j.1523-1755.2002.00191.x

21. Zimmermann E.M., Li L., Hou Y.T., Cannon M., Christman G.M., Bitar K.N. (1997). IGF-I induces collagen and IGFBP-5 mRNA in rat intestinal smooth muscle. Am J Physiol, 273 (4 Pt 1), G875-G882. https://doi.org/10.1152/ajpgi.1997.273.4.G875

22. Jiang D., Jiang Z., Li Z., Zhang Y. (2008). Suppression of the production of extracellular matrix and alpha-smooth muscle actin induced by transforming growth factor-beta1 in fibroblasts of the flexor tendon sheath by hepatocyte growth factor. Scand J Plast Reconstr Surg Hand Surg, 42, 169-173. https://doi.org/10.1080/02844310802045277

23. Liu H.J., Wu C.T., Duan H.F., Wu B., Lu Z.Z., Wang L. (2006). Adenoviralmediated gene expression of hepatocyte growth factor prevents postoperative peritoneal adhesion in a rat model. Surgery, 140(3), 441-447. https://doi.org/10.1016/j.surg.2005.12.014

24. Powell D.W., Mifflin R.C., Valentich J.D., Crowe S.E., Saada J.I., West A.B. (1999). Myofibroblasts. I. Paracrine cells important in health and disease. Am J Physiol, 277, C1-C9. https://doi.org/10.1152/ajpcell.1999.277.1.C1

25. Teraoka H., Sawada T., Nishihara T., Yashiro M., Ohira M., Ishikawa T., Nishino H., Hirakawa K. (2001). Enhanced VEGF production and decreased immunogenicity induced by TGF- $\beta 1$ promote liver metastasis of pancreatic cancer. $\mathrm{Br}$ J Cancer, 85, 612-617. https://doi.org/10.1054/bjoc.2001.1941

26. Hellström A., Carlsson B., Niklasson A., Segnestam K., Boguszewski M., de Lacerda L., Savage M., Svensson E., Smith L., Weinberger D., Wikland K.A., Laron Z. (2002). IGF-I is critical for normal vascularization of the human retina. collagen mRNAs in intestinal smooth muscle cells. J Clin Endocrinol Metab, 87, 3413-3416. https://doi.org/10.1210/jcem.87.7.8629

27. Conti E., Carrozza C., Capoluongo E., Volpe M., Crea F., Zuppi C., Andreotti F. (2004). Insulin-like growth factor-1 as a vascular protective factor. Circulation, 110, 2260-2265. https://doi.org/10.1161/01.CIR.0000144309.87183.FB

28. Ratti S., Curnis F., Longhi R., Colombo B., Gasparri A., Magni F., Manera E., Metz-Boutigue M.H., Corti A. (2000). Structure-activity relationships of chromogranin A in cell adhesion. Identification of an adhesion site for fibroblasts and smooth muscle cells. J Biol Chem, 275, 29257-29263.

https://doi.org/10.1074/jbc.M003796200 
29. Dondossola E., Gasparri A., Bachi A., Longhi R., Metz-Boutigue M.H., Tota B., Helle K.B., Curnis F., Corti A. (2010). Role of vasostatin-1 C-terminal region in fibroblast cell adhesion. Cell Mol Life Sci, 67, 2107-2118. https://doi.org/10.1007/s00018-010-0319-5

30. Mou S., Wang Q., Shi B., Gu L., Ni Z. (2009). Hepatocyte growth factor suppresses transforming growth factor-beta-1 and type III collagen in human primary renal fibroblasts. Kaohsiung J Med Sci, 25, 577-587. https://doi.org/10.1016/S1607-551X(09)70560-1

31. Cheng N., Chytil A., Shyr Y., Joly A., Moses H.L. (2008). Transforming growth factor-beta signaling-deficient fibroblasts enhance hepatocyte growth factor signaling in mammary carcinoma cells to promote scattering and invasion. Mol Cancer Res, 6, 1521-1533. https://doi.org/10.1158/1541-7786.MCR-07-2203

32. Wang P., Nishitani M.A., Tanimoto S., Kishimoto T., Fukumori T., Takahashi M., Kanayama H.O. (2007). Bladder cancer cell invasion is enhanced by crosstalk with fibroblasts through hepatocyte growth factor. Urology, 69, 780-784. https://doi.org/10.1016/j.urology.2007.01.063

33. Morishita R., Higaki J., Hayashi S.-I., Yol Y., Aoki M., Nakamura S., Moriguchi A., Matsushita H., Matsumoto K., Nakamura T., Ogihara T. (1997). Role of hepatocyte growth factor in endothelial regulation: prevention of high D-glucose-induced endothelial cell death by prostaglandins and phosphodiesterase type 3 inhibitor. Diabetalogia, 40, 1053-1061. https://doi.org/10.1007/s001250050787

34. Gong R., Rifai A., Tolbert E.M., Centracchio J.N., Dworkin L.D. (2003). Hepatocyte growth factor modulates matrix metalloproteinases and plasminogen activator/plasmin proteolytic pathways in progressive renal interstitial fibrosis. J Am Soc Nephrol, 14, 3047-3060. https://doi.org/10.1097/01.ASN.0000098686.72971.DB

35. Mizuno S., Matsumoto K., Nakamura T. (2001). Hepatocyte growth factor suppresses interstitial fibrosis in a mouse model of obstructive nephropathy. Kidney Int, 59, 1304-1314.

https://doi.org/10.1046/j.1523-1755.2001.0590041304.x

36. Dworkin L.D., Gong R., Tolbert E., Centracchio J., Yano N., Zanabli A., Esparza A., Rifai A. (2004). Hepatocyte growth factor ameliorates progression of interstitial fibrosis in rats with established renal injury. Kidney Int, 65, 409-419. https://doi.org/10.1111/j.1523-1755.2004.00417.x

37. Hermanto U., Zong C.S., Li W., Wang L.H. (2002). RACK1, an insulin-like growth factor I (IGF-I) receptor-interacting protein, modulates IGF-Idependent integrin signaling and promotes cell spreading and contact with extracellular matrix. Mol Cell Biol, 22, 2345-2365.

https://doi.org/10.1128/MCB.22.7.2345-2365.2002 
Address for correspondence:

Māra Pilmane

Institute of Anatomy and Anthropology

Riga Stradiņš University

Dzirciema street 16, Riga, LV 1007, Latvia

E mail: pilmane@latnet.lv 